\title{
European Union Tourism Policy: An Institutional Theory Critical Discourse Analysis
}

1) Judith Estol, University of Barcelona, Barcelona, Spain.

2) Mark Anthony Camilleri, University of Malta, Malta and University of Edinburgh, Scotland.

3) Xavier Font, University of Surrey, United Kingdom.

This is a pre-publication version.

How to Cite: Estol, J., Camilleri, M.A. \& Font, X. (2018). European Union Tourism Policy: An Institutional Theory Critical Discourse Analysis. Tourism Review.

\section{Purpose}

This research uses the institutional theory perspective to better understand the social dynamics of the European Union (EU) tourism policy and its directions.

\section{Design/methodology/approach}

A thorough literature review involving a critical discourse analysis on the regulative, normative and cultural elements of institutionalisation improves our understanding of the EU policy, in terms of its processes, content and outcomes. Therefore, this paper explores how the European institutions have incrementally legitimised tourism policy among Member States.

\section{Findings}

Over the years, the EU's policies were intended to enhance the European single market whilst supporting the growth of the industrial competitiveness, sustainable innovation and entrepreneurship. This has inevitably led to the development of new policies in the realms of tourism.

\section{Originality value}

This contribution has identified a gap in academic research as it reports about the evolution of EU tourism policy and on the conditions of how it has been planned, organised and implemented. It also exposes the challenges of institutionalising tourism policy in intergovernmental institutions.

Keywords: tourism policy, competitiveness, sustainability, legitimisation, institutional theory 


\section{Introduction and Methodology}

The European Union (EU) operates through the economic and political intergovernmental organisation of its member states. It involves a system of supranational independent institutions (Schmidt, 2013; Bulmer, 1993). When it comes to policy making, either the EU institutions or the Member States can initiate decision making processes, via interconnected networks of stakeholders at supranational, national and/or sub-national (regional) levels (Boukas \& Ziakas, 2016; Garcia, 2014; Anastasiadou, 2008; Bache \& Flinders, 2004). Hence, this review paper explores the EU's institutionalisation of tourism by examining a non-exhaustive list of academic papers, policies and reports (Estol \& Font, 2016; Hall, 2011). To this end, it employs a critical discourse analysis (Weiss \& Wodak, 2007) of online documents. It uses the institutional theory (Fligstein, 2001; Hix, 1998) to explore how the EU is continuously mandating and legitimising its tourismrelated policies through intergovernmentalism (Wan \& Bramwell, 2015; Camilleri, 2014; Moravcsik, 1993).

Therefore, this research critically analyses the EU's economic and political intergovernmental processes and their impact on tourism policy (Costa, Panyik \& Buhalis, 2014). It specifically considers three elements that institutionalise organisations: a) regulative: coercive isomorphism, compliance by expedience, rules, laws and sanctions; b) cultural-cognitive: mimetic isomorphism i.e. elements that are taken for granted; and c) normative: normative isomorphism, compliance by social obligation, certification and accreditations (Mizruchi \& Fein, 1999). These elements facilitate our comprehension of the tourism policies that emanate from the European Commission (EC).

Firstly, this paper evaluates EC's cultural-cognitive actions when it takes the lead over Member States on tourism approaches. Secondly, it critically analyses the EU's normative actions on issues regarding sustainability, competitiveness, multilevelgovernance and/or the impact of Europeanisation on the tourism industry (Castellani \& Sala, 2010). Hence, a tripartite categorisation of the European legislation explains the European tourism policy in terms of its processes, content and outcomes. This is carried out, through the lens of the Institutional Theory. Therefore, this contribution sheds light on the EU's institutional framework by using discourse analysis (Weiss \& Wodak, 2007). 
It analyses how the European institutions have incrementally legitimised tourism policy among Member States, as explicated in Table 1.

Table 1: Critical Discourse Analysis Questions

\begin{tabular}{|c|c|}
\hline IT framework & Discourse Analysis questions \\
\hline $\begin{array}{c}\text { Processes of creating } \\
\text { tourism policy }\end{array}$ & $\begin{array}{c}\text { How are the policies created? Who are the primary } \\
\text { stakeholders? How consistent are the policies? }\end{array}$ \\
\hline Content of tourism policy & $\begin{array}{c}\text { What traces of other policies are evident? Are there } \\
\text { any contradictions, and if so, how are they managed? } \\
\text { What is being normalised? }\end{array}$ \\
\hline Outcomes of tourism policy & $\begin{array}{c}\text { Who, primarily, are the policies aimed at? } \\
\text { What are the likely effects? }\end{array}$ \\
\hline
\end{tabular}

(Adapted from Jupp, 2006)

\section{Findings pertaining to Processes: Creating tourism policy without a mandate}

The Treaty on European Union (also known as the Maastricht Treaty) that was intended to integrate Europe had introduced tourism as a 'common measure' that had to be enacted in a subsidiary way among European institutions (art.3), particularly; when Member States' policies were insufficient to achieve the objectives of the Union (TEU, 1992). Initially, the Member States interacted according to their domestic interests (Marks, Hooghe, \& Blank, 1996) because their tourism policies and the distribution of their competences varied depending on the degree of governmental intervention. The Member States favoured the partial intervention on planning, promoting and controlling tourism; while tourism generating countries favoured the market-based rules (Lickorish, 1991).

As a result of the economic downturn in the 1980s, the credibility of the European institutions became a matter of debate (Moy, 1985). In response, the EC developed three Single Market (SM) approaches to re-institutionalise European institutions. First, the commission has set up a political space to discuss the reform of institutions and the implementation of the SM. Second, they pressurised Member States into accepting the SM in order to achieve full implementation before 1992. Third, they acted as an institutional entrepreneur, by building a common framework around the SM (Fligstein, 2001). A reluctant private sector has influenced the EU policies more effectively than the national authorities (Boukas \& Ziakas, 2016; Garcia, 2014; Anastasiadou, 2008). Lobbying organisations dedicated substantial resources to influencing policy or chasing EU funding (Anastasiadou, 2011). The consumer and environmental interest groups were 
powerful in shaping the 'Future of European Tourism' (Anastasiadou, 2007). One of the EC's first direct actions that has affected the European institutionalisation of tourism was primarily triggered via official communications about the initial guidelines for a 'Community Tourism policy' (EC, 1982). Moreover, European institutions, such as the European Parliament (EP) and the European Economic and Social Policy (EESC), reacted by formulating opinions that were in tune with the Communication, thus furthering mimetic isomorphism (EP, 1984; ESC, 1983).

As a result, the EC legitimised and normalised their intervention in tourism by emphasising efficiency, as it specified the role of the market and its relationship with the stakeholders (Hall, 2011). By doing so, it helped the tourism market to be organised around European institutions, while encouraging regional and local levels of governance to participate in the process of an institutionalised tourism policy. The European Year of Tourism (COUNCIL, 1989) the 'action plan of tourism for 1993-1995' (COUNCIL, 1992), the Green Book of the EC on 'the role of the Union on tourism' (EC, 1995) and the Philoxenia Program (EC, 1996) have resulted from the actions taken by the Council and the EC to create a greater place for tourism within the European institutions. The 'Pluriannual Program of community measures for Tourism' (EC, 1996) envisaged the strengthening of the horizontal approach to tourism and have supported specific tourism actions in the EC (Estol \& Font, 2016; Rodríguez, Williams \& Hall, 2014). Hence, the European rules had generated a self-sustaining dynamic that legitimised the EU as a tourism stakeholder (Wan \& Bramwell, 2015; Sweet \& Sandholtz, 1997).

The regional governments created networks with the EC and with subnational actors from different Member States. They also advanced the cause for the intervention of the private sector who, through interest groups, sought to influence the development of government policy (Wang \& Xu, 2014; Hall, 2011). Consequently, regional governments set up representations in Brussels and national governments have progressively lost control of their decision making (Estol \& Font, 2016; Boukas \& Ziakas, 2016; Garcia, 2014). However, the environment created by the EU policies enabled more indirect intervention of the EC, through the standardisation of hotel information, safety and security, and timesharing (Stavrinoudis, Tsartas \& Papatheodorou, 2013).

European tourism policy was further institutionalised by the Lisbon Treaty with art.6 and art.195 (TFEU, 2007). Therefore, the EU commission has recognised the rights, freedoms and principles that were set out in the Charter of Fundamental Rights of the 
European Union (art. 6). In addition, the commission has complemented the action of the Member States by encouraging the creation of a favourable environment for the development of tourism businesses; and by promoting closer cooperation between Member States through the exchange of good practice (art. 195).

Firstly, the European Employment Strategy that was initiated by the Luxembourg Jobs Summit in 1997, had imposed an objective to coordinate national employment policies. This strategy established the Open Method of Coordination of working between Member States and the EC; it was designed to encourage an integrated approach to maintain consistent employment, social issues, education, taxation, regional development and industry policies. Secondly, the Treaty of Amsterdam (that amended the Treaty of the European Union) had introduced the principle of sustainable development as a core EU objective, to be integrated at all levels, policies and actions. Together, these two actions have reinforced and institutionalised a tangible tourism framework that helped, at both the national and regional levels, to create new patterns of transnational interactions.

These treaties, together with the White Paper on European Governance confirmed that the reform of the European governance process was one of the EU's four strategic objectives (EC, 2001a). Thus, European institutions have recognised a policy-making process that allowed the EC to adopt concrete actions with regard to tourism. This has enabled an increasing number of people and organisations to be involved in shaping and delivering policy. The aim of this White Paper was to promote transparency, accountability and responsibility for all those involved. The initiatives outlined above were gathered together in the communication 'working together for the future of European Tourism' (EC, 2001b). This reference document had recognised that there was multilevel governance in tourism.

Following the Gothenburg Summit in 2001, the Council further strengthened its role by shifting its rhetoric to the terms "balancing sustainable development and competitiveness" (Camilleri, 2014). These terms became embedded in the European policies and provided further legitimisation for EU policy-making (Wan \& Bramwell, 2015). Therefore, the EC communicated on the basic orientations for the 'sustainability of European Tourism' (EC, 2003) and on the 'Agenda for sustainable and competitive European Tourism' (EC, 2007a) that comprised related subjects, including; the environment, employment, transport, heritage, rural development and culture (e.g. the Ecolabel certification, the Blue Flag programme for beaches and marinas, legislation on 
passengers' rights when travelling, and the like. The This institutionalisation of the tourism policy process was made, de facto, via policies in the areas of agriculture, regional policy, fisheries and maritime affairs, transport, information society, culture, environment, immigration and monetary issues, among others.)(EU, 2007b: Ritchie \& Crouch, 2003; Costa, Manente \& Furlan, 2001). The EU had formulated policies and proposals policy that had an effect on tourism, either directly or indirectly (EU, 2007b). At the time, the European Parliament's directorate for internal policies of the Union suggested that: (i) different policy areas concerned the same element of the tourism system (e.g. local resources, tourism enterprises, demand, etc) but had different aims; (ii) proposals made under different policy areas concerned different elements of the tourism system but were aiming at the same objective; and (iii) the proposals that were made under different policy areas concerned the same element of the tourism system and had the same objective. Therefore, EU (2007b) recommended a coherent approach in policy formulation in order to improve the competitiveness and sustainability of tourism.

The EU institutions' multilevel interaction became indispensable, as reflected in the Lisbon Treaty (art.195 TFEU, 2007). Furthermore, the isomorphism between European and multilevel domestic initiatives was framed in the communication 'on Europe, the World's No 1 Tourist Destination - A New Political Framework for Tourism in Europe' (EC, 2010). From this point on, the breadth and depth of institutionalisation of tourism became more extensive, as evidenced in the 'Maritime Integrated Strategy', the 'Multiannual Financial Framework', the 'European Job Mobility Portal', the 'Virtual Tourism Observatory', and many others.

\section{Findings pertaining to Content: Converging Policies and the Sustainable Development Principle}

Two components help us understand the content of tourism policy. The first component involves the convergence of the European policies in tourism. This convergence has resulted from the European Integration as promoted by the SM. The second component is the introduction of institutional interactions between the public and private actors; within networking structures; among central authorities and territorial units; and the interactions with or without the institutionalised instruments (Treib, Bähr, \& Falkner, 2007). Both components are still running in parallel today and are mutually dependent. 
The European tourism policy has adopted the language of sustainable tourism (Castellani $\&$ Sala, 2010). The European Community aligned the environment and competitiveness issues as instruments for the internal market (EC, 2011; Hey, 2005; Porter \& Van der Linde, 1995). The sustainable development principle had to be integrated into all European policies, and the Social Cohesion policy has made regional convergence one of the principal matters to be achieved by the European Community (TEU, 1997). The European Regional Development Funding had allocated an important part of the EU's budget to delivering the Social Cohesion policy (Bachtler \& Wren, 2006) and the Member States implemented it through regional projects. The Social Cohesion policy attributed responsibilities to actors (local and regional governments), deployed financial instruments so that everybody followed the same objectives and strategies (Estol \& Font, 2016).

The European Community has created a framework that institutionalised sustainable tourism policy as a means of enhancing local development (Camilleri, 2014; Castellani $\&$ Sala, 2010). There was an effort to combine the environmental protection with social cohesion (TEU, 1997). Both regional and local governments were increasingly employing different institutional arrangements for stakeholder engagement and environmental management to foster a climate for business development in the realms of tourism (Camilleri, 2014; Choi \& Sirakaya, 2006). However, the EC had come up with different measures and outcomes by using its set criteria (Bachtler \& Wren, 2006), in order to find a balance between environmental sustainability and the need for competitiveness (Hey, 2005). The tourism sector was ideally placed to operationalise such policies. In fact, the treaty of Amsterdam art. 174 gave due regard to both the Brundtland Report (1989), and to the integrated development of the regions (see TEU, 1997).

One of the EC's first steps to institutionalise tourism was to regard tourism as a key factor both in regional development and in environmental protection, while the internal market was mentioned because of its binding effect $(\mathrm{EC}, 1991)$. Europeanisation exists when the domestic change is driven by policy makers who take into consideration the perceived norm of how Europe would act in response to a particular set of circumstances (Grabbe, 2001). Alternatively, it could exist when change at a domestic level is coercively forced by the EU institutions. Tourist destinations in Member States became part of a process of new regionalism following their country's accession to the EU (Lovering, 1999). Local 
and regional governments were, and still are to a certain extent, key to the implementation and development of tourism policy.

The transversal character of tourism, the EC planned to implement concrete measures by using an integrative approach with other European policies. As a result, EC's communication on the 'Agenda for a sustainable and competitive European tourism' was recognised at different levels of government (EC, 2007c). Regional and local networks were founded with the aim of implementing Agenda 2007. Subsequently, a set of indicators were developed by the EC in order to help destinations to anticipate and to measure impacts, to build their brand, and to formulate policy on sustainable tourism.

The regional and environmental policies were central to the institutionalisation process. The sustainable tourism agenda gained popularity in national, regional and local levels (Camilleri, 2014; Ritchie \& Crouch, 2003; Berry \& Ladkin, 1997). However, it was important to establish how tourism businesses and destinations perceived sustainability and how their perceptions were related to competitiveness. This issue was reflected in the Communication on 'working together' (EC, 2001b). At the time, there were just a few Member States who participated in the discussions about the enactment of sustainability strategies and their and performance measurement (Dinica, 2009).

Some academic commentators argued that the market orientation of European policy, with its producer and consumer directorates, had marginalised non-market interests (Buhalis, 2000; Aspinwall \& Schneider, 2000). Evidence of this effect within the tourism sector can be noticed by looking at the degree of conformity with EC's developed standards, environmental certifications, including ecolabels (Anastasiadou, 2011). For example, EU-funded projects that promoted Social Cohesion policy has resulted in the voluntary participation in standard-setting and in the sustainable management of several EU destinations (EC, 2001b). Ecolabels, certifications and corporate social responsibility frameworks were seen as marketing tools for businesses (Camilleri, 2015). However, these regulatory instruments had a regulative character that institutionalise tourism within EU policy-making (Estol \& Font, 2016). In summary, the general adoption of Agenda 2007's guidance on sustainable tourism has reinforced the EC's role and importance regarding European tourism policy. Regional and local tourism networks were functioning as a bridge for the exchange of good practices between regions within Member States. These networks led to the development of collaborative relationships among tourism stakeholders. The EC has progressed and is still progressing in the 
institutionalisation of tourism policy. This institutionalisation requires time and commitment from Member States and stakeholders (Estol \& Font, 2016; Hall, 2011).

\section{Findings pertaining to Outcomes: Legitimacy and Compliance}

Tourism has prominently featured on the EC's agenda whenever European institutions have faced a crisis situation, whether economic, social or institutional. This is because tourism has been an easy option to deliver on the harmonisation of the SM, state aid and redistribution of resources; with the outcome of restricting the re-distributional capacity of Member States (Hix, 1998). Estol and Font (2016) argued that the removal of barriers to trade, had proceeded faster than the 'positive integration' measures such as welfare policies. The EC has prioritised market-based mechanisms from a liberal normative bias (Aspinwall \& Schneider, 2000). While the position of Member States with regard to tourism has not changed significantly over the years, the EC has been successful in developing instruments and methodologies relating to tourism, both within and outside the framework of the treaties; by harmonising previous policies and introducing new ways of making policy. The EU's legitimacy is based on the principles of competitiveness and sustainability (Schmidt, 2013). Essentially, the introduction of these two principles into the European policy arena was an important enabler that promoted the business case for sustainable tourism (Camilleri, 2014; Ritchie \& Crouch, 2003). The sustainable development principle, together with the White Paper on Governance, the open method of co-ordination and the Lisbon strategy, have also re-enforced the construction of tourism policy (Estol \& Font, 2016). The EC developed a governance model that combined regulatory and economic instruments with new voluntary policy instruments (Borrás \& Radaelli, 2011; EC, 2001b). The EC will usually prepare 'impact assessments' which set out the advantages and disadvantages of possible policy options and initiatives. It also consults with interested parties such as non-governmental organisations, local authorities and representatives of industry and civil society. Citizens, businesses and organisations can also participate in the EC's consultation procedure via a public consultation website. Afterwards, the European Parliament and the Council are entrusted to review proposals by the Commission and may propose amendments. Alternatively, both the Council and the Parliament may block the legislative proposals and policy instruments (EU, 2018).

This model allowed the EC to reinforce the institutionalisation of tourism thereby creating a microsystem based on a holistic approach that involved the engagement of private and 
public sectors, as reflected in the 'working together' communication (EC, 2001b). This manifested itself in Agenda 2007 (EC, 2007c). This communication was intended to develop a sustainable and competitive tourism strategy for Europe. Its win-win proposition was were well-received by the sector, leading to further legitimisation of the EU's institutions. However, the EU's regulative institutionalisation is based on the subsidiarity principle, where the EC adopts a subsidiary role to the respective governments of the Member States; with the overt intent of achieving harmonisation.

From a normative point of view, the EC founded the pillars of governance. Its different levels of governance may impose legitimacy constraints for the effective implementation of the policy (Bramwell, 2011; Jamal \& Getz, 1995). Moreover, different Member States would not possess the same resources, skills and capabilities to implement sustainable tourism practices (Dwyer \& Kim, 2003; Ritchie \& Crouch, 2003). Thus, diverse institutions may have reached different levels of compliance. The process of the EU's institutionalisation was and still is somewhat fragmented (Estol \& Font, 2016; Costa et al., 2014). Businesses may embrace, or not embrace sustainability for ethical reasons, or for pragmatic reasons (Camilleri, 2015; Hultsman, 1995). On a positive note, the EU's sustainable tourism initiatives, particularly the 'European Destinations of Excellence' (EDEN) and CALYPSO, among others are facilitating stakeholder involvement and developing networks among tourism providers (Panyik \& Anastasiadou, 2013; EC, 2011). These networks were purposely created to develop isomorphism and to foster a cultural need (Estol \& Font, 2016). From the outset, it may appear that such networks do not require conformity to specific criteria for controlling, planning, predicting or making policy in a sustainable way. Member States have often used their own criteria and policies for identifying viable destinations as they select winners, rather than endorsing the principles of European sustainable tourism (Estol \& Font, 2016). Yet, the continuity of these destination marketing initiatives is a demonstration of the European commitment on tourism. The EU institutions gain their legitimacy when the national governments, regions and tourism service providers collaborate together. At the same time, the local destinations gain visibility and recognition through an active participation in the European networks and beyond (Schmidt, 2013; Clarke \& Raffay, 2013). The EC's policy endeavours are intended to enhance the visibility of Europe as a tourist destination and increase international tourist arrivals. The EU's tourism page will be promoting the year 2018 as the EU-China Tourism Year (ECTY). 
It may appear that most of the European tourism policy initiatives are focusing on identifying best practices in sustainable tourism as well as on related topics, including; coastal and maritime tourism, cultural tourism, accessible tourism and low-season tourism; which could be improved with increased exchanges between different member states(EC, 2011). Nevertheless, the coordination of sustainable tourism activities of a large group of stakeholders still remains a challenge at the EC's inter-governmental level.

\section{Conclusions}

This paper has responded to the call for further research on the process of the EU's acquired competence in tourism policy (Panyik \& Anastasiadou, 2013). It explored how the European institutions have incrementally legitimised their presence among agents. This research suggested that the EC has become a skilful regulatory body in putting forward its institutional norms. In sum, the objective of EU tourism policy is to assist in European integration and the creation of a single market. The process for the Europeanisation of policies has been to allocate funds for tourism under the umbrella of regional development, thus creating a mandate for tourism policy. However, the European formulation of policy instruments involves specified procedures from different EU institutions, as well as their prospective ratification from individual member states. Consequently, these issues may be considered as the root causes of the ongoing nature of the EU's institutionalisation process. The content of the European tourism policy resulted from the standardisation of previously existing practices or from policies that were created for previously unregulated fields, including the environment, cultural and / or accessible tourism. The key principles of competitiveness, and the extension of regulations on the environment and social cohesion, amongst other areas, have added value to the long-term sustainability of the tourism industry. In sum, this contribution suggests that the EU's tourism policy and its mandate for competitiveness and sustainability is seeking win-win approaches for the EC, national governments and tourism stakeholders. The outcome of EU tourism policy has been the progressive legitimisation of the EU as a tourism institution, while concurrently weakening the devolution of its Member States in the formulation of tourism policy. 


\section{References}

Anastasiadou, C. (2007). Group Politics and Tourism Interest Representation at the Supranational Level: Evidence from the European Union. In P. Burns \& M. Novelli (Eds.), Tourism and Politics: Global Frameworks and Local Realities (pp. 59-70). Oxford: Elsevier.

Anastasiadou, C. (2008). Tourism interest groups in the EU policy arena: characteristics, relationships and challenges. Current Issues in Tourism, 11(1), 24-62.

Anastasiadou, C. (2011). Promoting Sustainability From Above: reflections on the influence of the European Union on tourism governance. Policy Quarterly Journal, 7(4), 27-33.

Aspinwall, M. D., \& Schneider, G. (2000). Same menu, separete tables: The institutionalist turn in political science and the study of European integration. European Journal of Political Research, 38(1), 1-36.

Bachtler, J., \& Wren, C. (2006). Evaluation of European Union cohesion policy: research questions and policy challenges. Regional Studies, 40(02), 143-153.

Bache, I., \& Flinders, M. (2004). Multi-level governance and the study of the British state. Public Policy and Administration, 19(1), 31-51.

Berry, S., \& Ladkin, A. (1997). Sustainable tourism: A regional perspective. Tourism Management, 18(7), 433-440.

Borrás, S., \& Radaelli, C. M. (2011). The politics of governance architectures: creation, change and effects of the EU Lisbon Strategy. Journal of European Public Policy, $18(4), 463-484$.

Boukas, N., \& Ziakas, V. (2016). Tourism policy and residents' well-being in Cyprus: Opportunities and challenges for developing an inside-out destination management approach. Journal of Destination Marketing \& Management, 5(1), 44-54.

Bramwell, B. (2011). Governance, the state and sustainable tourism: A political economy approach. Journal of Sustainable Tourism, 19(4-5), 459-477.

Brundtland, G. H. (1987). Report of the World Commission on environment and development:" our common future.. United Nations.

Buhalis, D. (2000). Marketing the competitive destination of the future. Tourism management, 21(1), 97-116. 
Bulmer, S. J. (1993). The governance of the European Union: a new institutionalist approach. Journal of public policy, 13(4), 351-380.

Camilleri, M. (2014). Advancing the sustainable tourism agenda through strategic CSR perspectives. Tourism Planning \& Development, 11(1), 42-56.

Camilleri, M. A. (2015). Valuing stakeholder engagement and sustainability reporting. Corporate Reputation Review, 18(3), 210-222.

Castellani, V., \& Sala, S. (2010). Sustainable performance index for tourism policy development. Tourism Management, 31(6), 871-880.

Choi, H. C., \& Sirakaya, E. (2006). Sustainability indicators for managing community tourism. Tourism management, 27(6), 1274-1289.

Clarke, A., \& Raffay, A. (2013). Benchmarking tourism partnerships. In C. Costa, E. Panyik, \& D. Buhalis (Eds.), Trends in European tourism planning and organisation (pp. 102-). Bristol: Channel View Publications.

Costa, P., Manente, M., \& Furlan, M. C. (Eds.). (2001). Politica economica del turismo: lezioni, modelli di gestione e casi di studio italiani e stranieri. Touring University Press, Milan, Italy .

Costa, C., Panyik, E., \& Buhalis, D. (Eds.). (2014). European Tourism Planning and Organisation Systems: The EU Member States (Vol. 61). Channel View Publications.

COUNCIL. (1989). 89/293/18 ECC, Council Decision on an action programme for the European Tourism Year (1990). Brussels, 17.11.1989: Retrieved from http://eurlex.europa.eu/legal-content/EN/TXT/?uri=CELEX\%3A31989D0046

COUNCIL. (1992). 92/421 CEE, Council Decision on a Community action plan to assist tourism. Brussels, 13.8.1992: Eur-lex Retrieved from http://eurlex.europa.eu/legal-content/EN/ALL/?uri=CELEX:31992D0421.

Dinica, V. (2009). Governance for sustainable tourism: a comparison of international and Dutch visions. Journal of Sustainable Tourism, 17(5), 583-603.

Dwyer, L., \& Kim, C. (2003). Destination competitiveness: determinants and indicators. Current issues in tourism, 6(5), 369-414.

EC. (1995). COM (95) 97 final, Communication of the Commission, Green Paper on the role of the Union in the field of tourism. http://www.europarl.europa.eu/sides/getDoc.do?type=REPORT\&mode=XML\& reference $=\mathrm{A} 4-1996-0016 \&$ language $=\mathrm{EN}$ 
EC. (1996). COM (96) 0168 final, Proposal of the Commission for a Council Decision on a first Multiannual Programme to assist European Tourism Philoxenia (19972000).http://eur-lex.europa.eu/legalcontent/EN/TXT/?uri=CELEX\%3A51996PC0168

EC. (2001a). COM (2001) 428 final, White Paper from the Commission of the European Communities on European Governance. http://eur-lex.europa.eu/legalcontent/EN/TXT/?uri=LEGISSUM:110109

EC. (2001b). COM (2001) 665 final, Communication from the Commission to the Council, the European Parliament, the Economic and Social Committe and the Comittee of Regions on working together for the future of European Tourism. http://eur-lex.europa.eu/legal-content/EN/TXT/?uri=COM:2017:0376:FIN

EC. (2003). COM (2003) 716 final, Communication from the Commission to the Council, the European Parliament, the Economic and Social Committee and the Committee of the Regions on basic orientations for the sustainability of European Tourism. http://eur-lex.europa.eu/legal-content/EN/TXT/?uri=CELEX:52003DC0716

EC. (2007a). COM (2007) 621 final, Communication from the Commission on Agenda for a sustainable and competitive European Tourism. http://eurlex.europa.eu/legal-content/EN/TXT/?uri=CELEX\%3A52007DC0621

EU (2007b). The Fragmentation of EU Tourism Policy. Policy Department Structural and Cohesion Policies - Transport and Tourism. European Parliament. Directorate General for Internal Policies of the Union. http://www.europarl.europa.eu/RegData/etudes/note/join/2007/389603/IPOLTRAN_NT(2007)389603_EN.pdf

EC. (2007c). COM (2007) 0575 final, Communication from the Commission to the European Parliament, the Council, the European Economic and Social Committee and the Committee of the Regions - An Integrated Maritime policy for the European Union: \{COM(2007) 574 final)\} \{SEC(2007) 1278\} \{SEC(2007) 1279\} \{SEC(2007) 1280\} \{SEC(2007) 1283\} http://eur-lex.europa.eu/legalcontent/EN/TXT/?uri=CELEX\%3A52007DC0575

EC. (2010). COM (2010) 352 final, Communication from the Commission to the Council, the European Parliament, the Economic and Social Committee and the Committee of the Regions on Europe, the World's No 1 Tourist Destination - A New Political Framework for Tourism in Europe. http://eur-lex.europa.eu/legalcontent/EN/ALL/?uri=celex:52010DC0352 
EC (2011). Proposal for a REGULATION OF THE EUROPEAN PARLIAMENT AND

OF THE COUNCIL establishing a Programme for the Competitiveness of Enterprises and small and medium-sized enterprises (2014 - 2020) http://eurlex.europa.eu/legal-content/EN/TXT/?uri=CELEX\%3A52011PC0834

ECSC (1951). Treaty establishing the European Coal and Steel Community, ECSC Treaty http://eur-lex.europa.eu/legal-content/EN/TXT/?uri=LEGISSUM:xy0022

EEC (1957). Treaty establishing the European Economic Community http://eurlex.europa.eu/legal-content/EN/TXT/?uri=celex:11957E/TXT

EU (2016). A European agenda for the collaborative economy https://ec.europa.eu/transparency/regdoc/rep/1/2016/EN/1-2016-356-EN-F1-1.PDF

EU (2018). How EU decisions are made. https://europa.eu/european-union/eulaw/decision-making/procedures_en

EP. (1984). DOC 1-816/83, Resolution of the European Parliament on Measures Affecting tourism. http://www.europarl.europa.eu/facts_2004/4_15_0_en.htm

ESC. (1983). ESC-84-004 EN, Opinion of the European and Social Committee on Tourism. http://eur-lex.europa.eu/legalcontent/EN/TXT/?uri=CELEX:31984Y0430(01)

Estol, J. and X. Font (2016). European tourism policy: Its evolution and structure. Tourism Management, 52: 230-241.

Fligstein, N. (2001). Institutional Entrepreneurs and Cultural Frames-The case of the European Union's SM Program. European Societies, 3(3), 261-287.

Garcia, F. A. (2014). A comparative study of the evolution of tourism policy in Spain and Portugal. Tourism Management Perspectives, 11, 34-50.

Garrod, B., \& Fyall, A. (1998). Beyond the rhetoric of sustainable tourism? Tourism Management, 19(3), 199-212.

Grabbe, H. (2001). How does Europeanization affect CEE governance? Conditionality, diffusion and diversity. Journal of European public policy, 8(6), 1013-1031.

Hall, C. M. (2011). A typology of governance and its implications for tourism policy analysis. Journal of Sustainable Tourism, 19(4-5), 437-457.

Hey, C. (2005). EU Environmental Policies: A short history of the policy strategies. Chapter, 3, 18-30.

Hix, S. (1998). The study of the European Union II: the 'new governance'agenda and its rival. Journal of European Public Policy, 5(1), 38-65. 
Hultsman, J. (1995). Just tourism: An ethical framework. Annals of Tourism Research, 22(3), 553-567.

Jamal, T. B., \& Getz, D. (1995). Collaboration theory and community tourism planning. Annals of tourism research, 22(1), 186-204.

Jupp, V. (2006). Decision-making. In Jupp, V. (Ed.) The Sage dictionary of social research methods. Thousand Oaks, CA: Sage, 74-76.

Lickorish, L. J. (1991). Developing a single European tourism policy. Tourism Management, 12(3), 178-184. doi: 10.1016/0261-5177(91)90001-a

Lovering, J. (1999). Theory led by policy: the inadequacies of the "new regionalism'(illustrated from the case of Wales). International journal of urban and regional research, 23(2), 379-395.

Marks, G., Hooghe, L., \& Blank, K. (1996). European Integration from the 1980s: StateCentric v. Multi-level Governance. JCMS: Journal of Common Market Studies, 34(3), 341-378.

Mizruchi, M. S., \& Fein, L. C. (1999). The social construction of organizational knowledge: A study of the uses of coercive, mimetic, and normative isomorphism. Administrative science quarterly, 44(4), 653-683.

Moravcsik, A. (1993). Preferences and power in the European Community: a liberal intergovernmentalist approach. JCMS: Journal of Common Market Studies, 31(4), 473-524.

Moy, J. (1985). "Recent Trends in Unemployment and the Labor Force: 10 Countries" (PDF). Monthly Labor Review. Bureau of Labor Statistics. 108 (8): 9-22. Retrieved 13 April 2011.

Panyik, E., \& Anastasiadou, C. (2013). Mapping the EU's Evolving Role in Tourism: Implications of the New EU Tourism Competence. In C. Costa, E. Panyik, \& D. Buhalis (Eds.), Trends in European Tourism Planning and Organisation (pp. 189207). Bristol: Channel View Publications.

Porter, M. E., \& Van der Linde, C. (1995). Toward a new conception of the environmentcompetitiveness relationship. The journal of economic perspectives, 9(4), 97-118.

Schmidt, V. A. (2013). Democracy and legitimacy in the European Union revisited: Input, output and 'throughput'. Political Studies, 61(1), 2-22.

Ritchie, J. B., \& Crouch, G. I. (2003). The competitive destination: A sustainable tourism perspective. Cabi, Oxford, U.K. 
Rodríguez, I., Williams, A. M., \& Hall, C. M. (2014). Tourism innovation policy: Implementation and outcomes. Annals of Tourism Research, 49, 76-93.

Stavrinoudis, T., Tsartas, P., \& Papatheodorou, A. (2013). Business environment and accommodation policies in Europe. Trends in European Tourism Planning and Organisation, Clevedon: Channel View Publications, 174-186.

Sweet, A. S., \& Sandholtz, W. (1997). European integration and supranational governance. Journal of European Public Policy, 4(3), 297-317.

TEU (1992). Treaty of Maastricht on European Union (1992). http://eurlex.europa.eu/legal-content/EN/TXT/?uri=LEGISSUM:xy0026

TEU (1997). Treaty of Amsterdam amending the Treaty on European Union, the Treaties establishing the European Communities and certain related acts. http://eurlex.europa.eu/legal-content/EN/TXT/?uri=CELEX\%3A11997D\%2FAFI

TFEU (2007). Treaty of Lisbon amending the Treaty on European Union and the Treaty establishing the European Community (2007). http://eur-lex.europa.eu/legalcontent/EN/ALL/?uri=OJ\%3AC\%3A2007\%3A306\%3ATOC

Treib, O., Bähr, H., \& Falkner, G. (2007). Modes of governance: towards a conceptual clarification. Journal of European Public Policy, 14(1), 1-20.

Wan, Y. K. P., \& Bramwell, B. (2015). Political economy and the emergence of a hybrid mode of governance of tourism planning. Tourism Management, 50, 316-327.

Wang, C., \& Xu, H. (2014). The role of local government and the private sector in China's tourism industry. Tourism Management, 45, 95-105.

Weiss, G., \& Wodak, R. (Eds.). (2007). Critical discourse analysis. Palgrave Macmillan, New York, USA. 